\title{
KMT2A Gene Mutation
}

National Cancer Institute

\section{Source}

National Cancer Institute. KMT2A Gene Mutation. NCI Thesaurus. Code C162513.

A change in the nucleotide sequence of the KMT2A gene. 